\title{
PERANCANGAN SISTEM KERJA UNTUK MENINGKATKAN PRODUKTIVITAS DENGAN PENDEKATAN SISTEM SOSIOTEKNIK
}

(Studi kasus di Kelompok Pengrajin Kipas Bambu, Bantul)

\author{
Puryani, Intan Berlianty, Purwanto \\ Program Studi Teknik Industri Fakultas Teknik Industri \\ Universitas pembangunan Nasional "Veteran" Yogyakarta \\ Jl. Babarsari 2 Tambakbayan, Yogyakarta, 55281 \\ Telp. (0274) 485363 Fak : (0274) 486256 email : jur_tiupn@telkom.net
}

\begin{abstract}
ABSTRAK
Usaha Kecil dan Menengah telah bertumbuh dan berkembang pesat di Indonesia. Di Kabupaten Bantul terdapat pusat kerajinan kipas yang berada di Dusun Jipangan, Kelurahan Bangunjiwo, Kecamatan Kasihan. Proses produksi yang terdapat pada UKM ini masih sangat sederhana sehingga tingkat produktivitasnya pun juga rendah. Oleh sebab itu, pemilik ingin menaikkan kemampuan produksinya dengan mengganti proses pengiratan dengan teknologi yang baru yang memiliki kemampuan produksi yang lebih tinggi. Dengan demikian, perlu dilakukan pemilihan alternatif teknologi yang baru sesuai keinginan pemilik UKM. Selanjutnya dilakukan penerapan ergonomi makro berdasarkan pendekatan sistem sosioteknik untuk merancangan sistem kerja yang baru dengan mempertimbangkan keinginan teknologi dari pemilik UKM.

Pada penelitian ini, pemilihan alternatif teknologi menggunakan metode Analytical Hierarchy Process (AHP). Pemilihan alternatif yang tepat nantinya akan berdampak pada desain sistem kerja yang baru. Penelitian ini bertujuan untuk membuat desain ulang sistem kerja yang diinginkan untuk meningkatkan produktivitas dengan penerapan ergonomi makro yang menggunakan pendekatan sistem sosioteknik dari pemilihan alternatif yang terpilih.

Berdasarkan hasil penelitian ini, telah diperoleh 6 kriteria dengan 15 sub kriteria yang dapat digunakan untuk pemilihan alternatif teknologi. Kriteria-kriteria tersebut diantaranya keahlian operator, upah operator, biaya, peningkatan fungsi, mudah digunakan, dan kenyamanan. Dari hasil perhitungan, didapatkan alternatif teknologi terbaik yaitu teknologi otomatis dengan bobot sebesar 0,658. Kemudian didapatkan desain sistem kerja yang baru yaitu dengan spesifikasi tenaga kerja dengan pendidikan minimal Diploma, melakukan pengadaan mesin irat bambu, serta lingkungan yang dekat dengan bahan baku, supplier, dan area pemasaran dan juga dengan tingkat produktivitas untuk penggunaan alternatif teknologi otomatis sebesar 0,019\%.
\end{abstract}

Kata kunci: Sistem Sosioteknik, Sistem Kerja, Pemilihan Alternatif Teknologi, AHP

\section{PENDAHULUAN}

Usaha Kecil dan Menengah (UKM) telah bertumbuh dan berkembang dengan pesat dari waktu ke waktu. Perkembangan pada sektor industri sangat berpengaruh langsung pada persaingan yang semakin meningkat. Pada kondisi tertentu, industri skala kecil akan tidak mampu bersaing dengan industri yang memiliki modal yang lebih besar. Industri kerajinan kipas bambu merupakan suatu kerajinan asli Indonesia yang saat ini banyak diminati banyak orang, terutama souvenir kipas pernikahan atau undangan pernikahan. Di daerah Jipangan terdapat kelompok industri kerajinan kipas, desa ini berada di Kabupaten Bantul. Usaha kerajinan kipas di desa Jipangan ini dimulai dari tahun 1987 dan hingga saat ini terdapat 52 pengrajin. Saat ini terdapat sebuah UKM pengrajin kipas dari Jipangan dengan nama Banyu Biru Craft. Kipas dari Jipangan ini menggunakan bahan baku bambu yaitu untuk membuat kerangka kipas. Proses pembuatan kipas ada beberapa tahapan yaitu pemotongan bambu, pengiratan, pembuatan kontur atau pengukiran, proses pemutihan bambu, proses pengeringan, dan finishing 
yang meliputi pemasangan renda dan pengemasan. Dalam proses pengiratan jumlah produksi yang dihasilkan masih sangat sedikit yaitu kemampuan produksi per harinya hanya 8 batang bambu. Oleh sebab itu, pemilik ingin menaikkan kemampuan produksinya sehingga dalam hal ini pemilik ingin mengganti proses pengiratannya dengan teknologi yang baru yang memiliki kemampuan produksi yang tinggi, untuk proses pengiratan saat ini hanya menggunakan pisau. Dengan kondisi sekarang ini yang masih serba manual, produk kerajinan kipas UKM Banyu Biru Craft masih kalah bersaing dengan produkproduk kipas bambu yang ada di daerah lain yang sudah menggunakan mesin dalam proses produksinya. Berdasarkan penjelasan diatas, maka penelitian ini bertujuan untuk mencari prioritas teknologi mana yang menjadi keinginan dari pemilik UKM Banyu Biru Craft untuk meningkatkan kemampuan produksi. Metode analytical hierarchy process (AHP) disini akan membantu dalam penentuan alternatif teknologi yang tepat untuk diterapkan di UKM Banyu Biru Craft. Kemudian dilakukan penerapan ergonomi makro dengan pendekatan sistem sosioteknik untuk merancangan sistem kerja yang baru dengan mempertimbangkan keinginan teknologi dari pemilik UKM.

\section{LANDASAN TEORI}

Sistem merupakan kumpulan dari elemen-elemen yang berinteraksi untuk mencapai suatu tujuan tertentu (Jogianto, 2005). Sedangkan kerja merupakan kegiatan untuk melakukan sesuatu, sehingga sistem kerja merupakan suatu rangkaian tata kerja dan prosedur kerja yang kemudian membentuk suatu pola tertentu dalam rangka melakukan suatu pekerjaan. Keberhasilan sistem kerja dapat dilihat dari efisiensi dan produktivitas yang tinggi (Sutalaksana, 1979).

Secara umum sistem manusia mesin didefinisikan sebagai "set of object together eith relationship between the object and between their attributes" (Wignjosoebroto,
2000). Suatu sistem akan terjadi dalam suatu lingkungan dan perubahan-perubahan yang timbul akibat lingkungan ini akan mempengaruhi sistem serta elemen-elemen sistem tersebut. Sistem itu dibagi ke dalam sub-sistem dan seterusnya. Dalam hal ini kaitannya dengan aktivitas manusia sebagai suatu sistem akan dapat pula dibagi-bagi ke dalam job operations (sub-sistem), job position (job sub-sistem), duties (komponen), task (unit), sub task (parts), dan task elemen (behavioral elements). Dalam kaitannya dengan sistem manusia mesin maka dikenal akan tiga macam hubungan yaitu : manual man machine system, semi automatic machine system, automatic man machine system.

Definisi ergonomi makro adalah pendekatan sistem sosioteknik secara topdown dalam menganalisis, merancang, atau memperbaiki sistem kerja dan organisasi kerja kemudian mengharmonisasikan perancangan tersebut ke dalam elemenelemennya secara keseluruhan (Iridiastadi dan Yassierli, 2014). Definisi konseptual ergonomi makro adalah pendekatan top-down secara sositeknikal yang diterapkan dalam perancangan sistem kerja secara keseluruhan pada interaksi human-job, human-manchine, dan human-software interface (Hendrick and Kleiner, 2001). Teori sosioteknik berfokus pada interaksi antara permintaan teknis dari pekerjaan dan permintaan sosial dari orang yang melakukan pekerjaan.

Untuk melakukan perancangan organisasi dibutuhkan analisis yang sistematis mengenai karakteristik kunci teknologi, personel subsystem, dan lingkungan eksternal yang relevan pada organisasi. Perancangan organisasi dengan konsep ergonomi makro harus memperhatikan hal-hal berikut (Iridiastadi dan Yassierli, 2014).

1. Harus berbasis pada manusia (human centered).

2. Harus menggunakan pendekatan manusiawi dalam perancangan alokasi tugas dan fungsi.

3. Harus mempertimbangkan variabel sistem sosioteknik yang relevan 
dalam implikasinya pada perancangan organisasi dan sistem kerja serta perancangan pekerjaan, proses kerja yang spesisfik, dan interface manusia-sistem.

Produktivitas secara bahasa berasal dari kata "produktiv" artinya yaitu sesuatu yang mengandung potensi untuk digali sehingga produktivitas dapat dikaitkan suatu proses kegiatan yang terstruktur guna menggali potensi yang ada dalam sebuah objek. Dilihat dari filosofi produktivitas sebenarnya dapat mengandung arti keinginan dan usaha dari setiap individu atau kelompok untuk selalu meningkatkan mutu kehidupan dan penghidupannya.

Metode analytical hierrarchy process (AHP) dikembangkan oleh Prof. Thomas Lorie Saaty dari Wharton Business School diawal tahun 1970, yang digunakan untuk mencari rangking atau urutan prioritas dari berbagai alternatif dalam pemecahan suatu permasalahan. Pada dasarnya AHP adalah suatu teori umum tentang pengukuran yang digunakan untuk menemukan skala rasio, baik dari perbandingan berpasangan yang diskrit maupun kontinyu. AHP dapat menyederhanakan masalah yang kompleks dan tidak terstruktur, strategik dan dinamik menjadi bagiannya, serta menjadikan variabel dalam suatu hirarki (tingkatan).

\section{METODOLOGI PENELITIAN}

\subsection{Obyek Penelitian}

Penelitian ini dilaksanakan di sentra kerajinan kipas bambu yang berada di Jipangan, Kasihan, Bantul. Pada penelitian ini, batasan sistem penelitian berada pada lingkungan kerja yang mencakup teknologi yang digunakan, tenaga kerja, dan lingkungan fisik.

\subsection{Data yang Digunakan}

Adapun data yang digunakan untuk pemilihan pemasok adalah sebagai berikut:

1. Data Alternatif

Alternatif dalam penelitian ini adalah teknologi yang akan dipilih oleh pihak pemilik dan pekerja dari UKM kerjinan kipas bambu.

\section{Data Kriteria}

Untuk mengidentifikasi kriteria dilakukan dengan melakukan wawancara terhadap pemilik dari UKM dengan menyesuaikan kondisi yang ada.

3. Data Bobot Kriteria

Data bobot kriteria diperoleh berdasarkan dari penilaian oleh pihak UKM. Bobot kriteria ini menunjukkan seberapa pentingkah kriteria tersebut menurut pihak UKM. Semakin tinggi bobot kriteria, maka semakin penting pula kriteria tersebut bagi UKM. Begitu juga dengan semakin rendahnya bobot kriteria, maka semakin tidak penting kriteria tersebut bagi pihak UKM

4. Data Alternatif Ditinjau dari MasingMasing Kriteria

Data ini merupakan data yang berkaitan dengan penilaian pihak UKM terhadap alternatif dari teknologi yang akan diterapkan ditinjau dari masing-masing kriteria. Sehingga dari data ini nantinya akan dilakukan perhitungan dan penentuan teknologi.

\subsection{Pengolahan Data}

Langkah yang dilakukan dalam pengolahan data dapat dilihat pada gambar 1. 


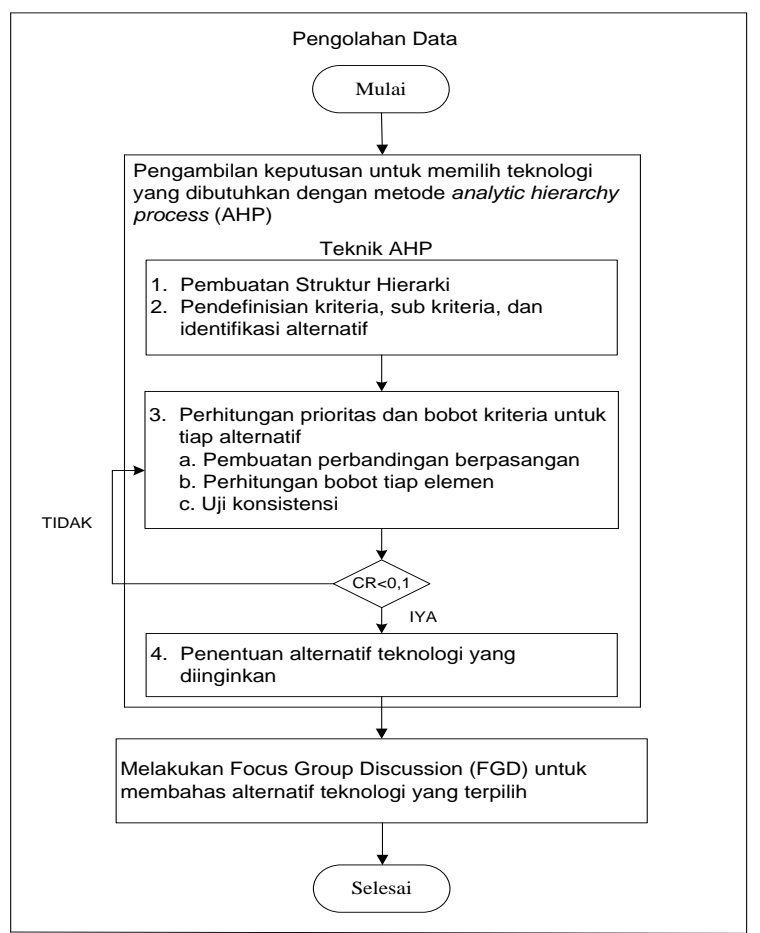

Gambar 1. Diagram alir pengolahan data

\section{PENGOLAHAN DATA DAN ANALISIS HASIL}

\subsection{Pengumpulan Data}

1. Data Kriteria

Tabel 1. Data kriteria

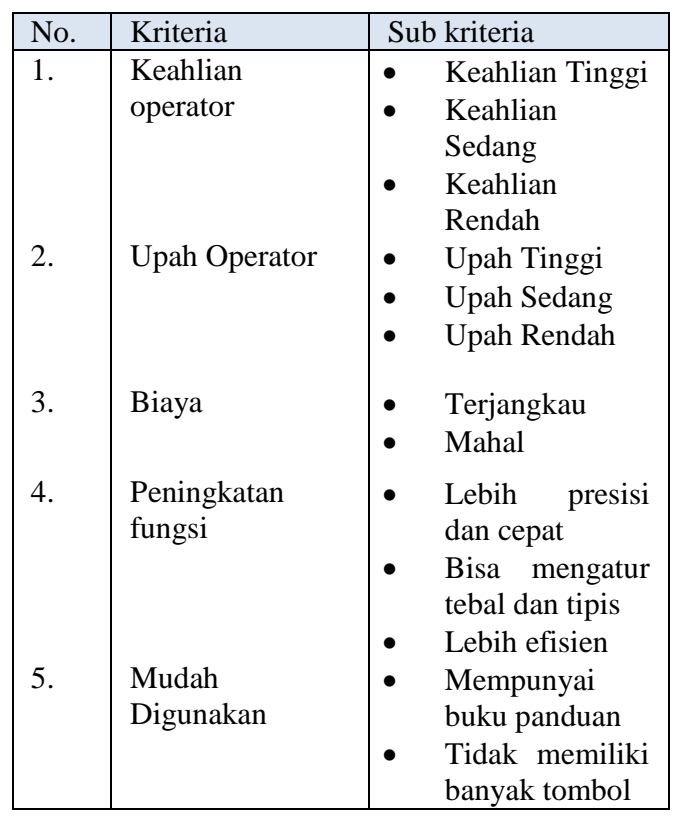

\begin{tabular}{|l|l|ll|}
\hline 6. & Kenyamanan & $\bullet$ & $\begin{array}{l}\text { Menyesuaikan } \\
\text { postur tubuh } \\
\text { Aman } \\
\text { digunakan }\end{array}$ \\
\hline
\end{tabular}

2. Data Bobot Kriteria

Tabel 2. Data bobot kriteria

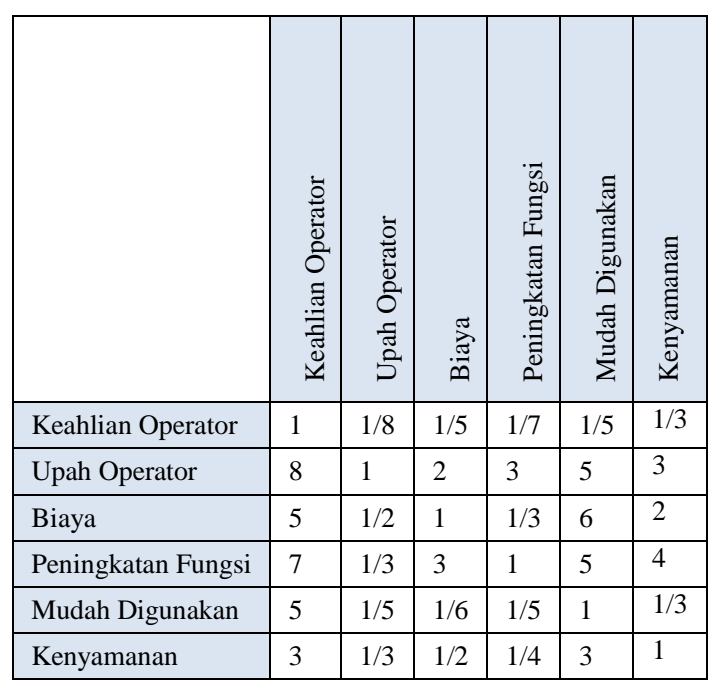

3. Data bobot sub kriteria ditinjau dari masing-masing kriteria

Berikut adalah rekap hasil kuesioner yang dilakukan kepada pengambil keputusan (PK) pada pemilik UKM Banyu Biru Craft berdasarkan kuesioner AHP yang sesuai dengan pertimbangan pengambil keputusan.

Tabel 3. Perbandingan berpasangan antar sub kriteria untuk kriteria keahlian operator

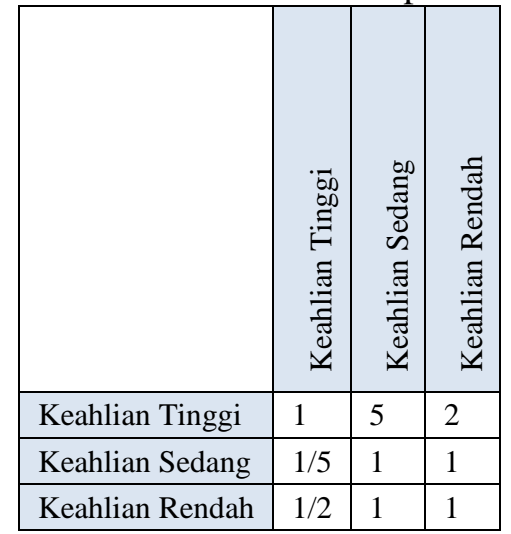


4. Data bobot alternatif ditinjau dari masing-masing sub kriteria

Berikut adalah rekap hasil kuesioner yang dilakukan kepada pengambil keputusan (PK) pada pemilik UKM Banyu Biru Craft berdasarkan kuesioner AHP yang sesuai dengan pertimbangan pengambil keputusan.

Tabel 4. Perbandingan berpasangan antar alternatif ditinjau dari sub kriteria keahlian tinggi

\begin{tabular}{|c|c|c|c|}
\hline & $\begin{array}{l}0 \\
\overline{0} \\
0 \\
0 \\
0 \\
50 \\
00 \\
0 \\
\frac{5}{0} \\
0\end{array}$ & 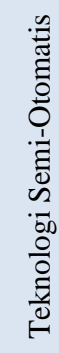 & 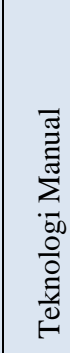 \\
\hline Teknologi Otomatis & 1 & 3 & 7 \\
\hline Teknologi Semi-Otomatis & $1 / 3$ & 1 & 5 \\
\hline Teknologi Manual & $1 / 7$ & $1 / 5$ & 1 \\
\hline
\end{tabular}

\subsection{Pengolahan Data}

4.2.1 Menentukan Kriteria, Sub Kriteria, dan Alternatif

Berdasarkan hasil dari wawancara dengan pemilik dan pekerja di UKM kerajinan kipas didapatkan kriteria dan sub kriteria untuk memilih teknologi yang akan diterapkan pada UKM tersebut agar bisa meningkatkan produktivitas dalam bekerja. Kriteria dan sub kriteria yang digunakan dalam penelitian ini yang dapat dilihat pada tabel 1. Adapun untuk alternatif penerapan teknologi yang digunakan yaitu teknologi manual, teknologi semi-otomatis, dan teknologi otomatis.

\subsubsection{Struktur Hierarki}

Membuat struktur hierarki masalah berdasarkan tujuan pemilihan, kriteria, danalternatif yang sudah terkumpul. Pembuatan hirarki permasalahan ini bertujuan untuk memudahkan dalam melakukan pemecahan masalah penentuan teknologi mana yang akan diterapkan.

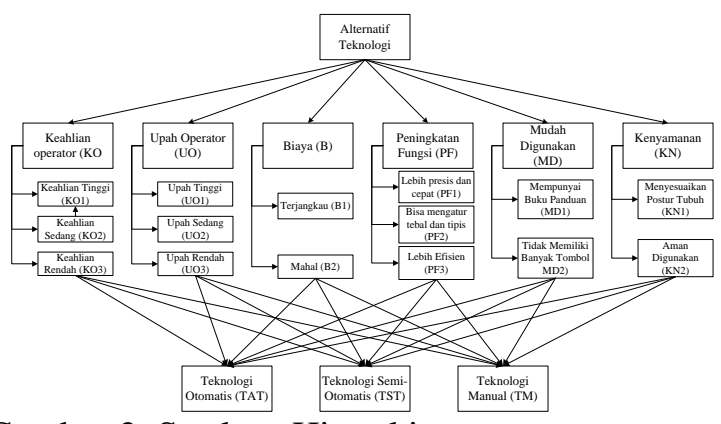

Gambar 2. Struktur Hierarki

\subsubsection{Uji Konsistensi Kuesioner} Perbandingan Berpasangan

Tabel 5. Matriks perbandingan berpasangan antar kriteria hasil normalisasi

\begin{tabular}{|l|l|l|l|l|l|l|}
\hline & KO & UO & B & PF & MD & KN \\
\hline KO & 1 & 0,125 & 0,2 & 0,143 & 0,2 & 0,333 \\
\hline UO & 8 & 1 & 2 & 3 & 5 & 3 \\
\hline B & 5 & 0,5 & 1 & 0,333 & 6 & 2 \\
\hline PF & 7 & 0,333 & 3 & 1 & 5 & 4 \\
\hline MD & 5 & 0,2 & 0,167 & 0,2 & 1 & 0,333 \\
\hline KN & 3 & 0,333 & 0,500 & 0,25 & 3 & 1 \\
\hline Total & $\mathbf{2 9}$ & $\mathbf{2 , 4 9 2}$ & $\mathbf{6 , 8 6 7}$ & $\mathbf{4 , 9 2 6}$ & $\mathbf{2 0 , 2}$ & $\mathbf{1 0 , 6 6 7}$ \\
\hline
\end{tabular}

Tabel 6. Matriks perhitungan prioritas kriteria

\begin{tabular}{|l|l|l|l|l|l|l|l|l|}
\hline & KO & UO & B & PF & MD & KN & $\sum$ & Bbt \\
\hline & 0,03 & 0,05 & 0,02 & 0,02 & 0,01 & 0,03 & 0,18 & 0,03 \\
KO & 4 & 0 & 9 & 9 & 0 & 1 & 4 & 1 \\
\hline & 0,27 & 0,40 & 0,29 & 0,60 & 0,24 & 0,28 & 2,10 & 0,35 \\
UO & 6 & 1 & 1 & 9 & 8 & 1 & 6 & 1 \\
\hline & 0,17 & 0,20 & 0,14 & 0,06 & 0,29 & 0,18 & 1,07 & 0,17 \\
B & 2 & 1 & 6 & 8 & 7 & 8 & 1 & 8 \\
\hline & 0,24 & 0,13 & 0,43 & 0,20 & 0,24 & 0,37 & 1,63 & 0,27 \\
PF & 1 & 4 & 7 & 3 & 8 & 5 & 8 & 3 \\
\hline & 0,17 & 0,08 & 0,02 & 0,04 & 0,05 & 0,03 & 0,39 & 0,06 \\
MD & 2 & 0 & 4 & 1 & 0 & 1 & 8 & 6 \\
\hline & 0,10 & 0,13 & 0,07 & 0,05 & 0,14 & 0,09 & 0,60 & 0,10 \\
KN & 3 & 4 & 3 & 1 & 9 & 4 & 3 & 1 \\
\hline & & & & 1 & 1 & 1 & $\mathbf{6}$ & $\mathbf{1}$ \\
tot & $\mathbf{1}$ & $\mathbf{1}$ & $\mathbf{1}$ & $\mathbf{1}$ & $\mathbf{1}$ & $\mathbf{1}$ \\
\hline
\end{tabular}

Tabel 7. Nilai CR pengambilan keputusan

\begin{tabular}{|l|l|l|l|}
\hline Eigen Vector & $\lambda$ & CI & CR \\
\hline 0,031 & & & \\
\cline { 1 - 1 } 0,351 & & & \\
\cline { 1 - 1 } 0,178 & \multirow{3}{*}{6,598} & 0,12 & 0,097 \\
\cline { 1 - 1 } 0,273 & & & \\
\cline { 1 - 1 } 0,066 & & & \\
\cline { 1 - 1 } 0,101 & & & \\
\hline
\end{tabular}


Perhitungan consistency ratio $(\mathrm{CR})$ oleh pengambil keputusan (PK).

Kriteria $=6$

$\mathrm{D}=\left[\frac{0,196}{0,031} \frac{2,405}{0,351} \frac{1,198}{0,178} \frac{1,874}{0,273} \frac{0,408}{0,066} \frac{0,066}{0,101}\right]=$ $\lceil 6,394 \quad 6,8526,710 \quad 6,866 \quad 6,141 \quad 6,627\rceil$

$\lambda_{\max }=\frac{6,394+6,852+6,710+6,866+6,141+6,627}{6}=6,598$

$\lambda_{\max }=6,598$

Consistency ratio $=\mathrm{CR}=\frac{\mathrm{CI}}{\mathrm{RI}}=\frac{0,12}{1,24}=0,097$

Karena CR $\leq 0,1$ maka penilaian konsisten dan data dapat dilanjutkan ke perhitungan selanjutnya.

4.2.4 Menghitung besarnya bobot prioritas alternatif terhadap sub kriteria

Menghitung bobot prioritas alternatif terhadap sub kriteria digunakan untuk mengetahui prioritas alternatif teknologi dengan masing-masing sub kriteria yang nantinya akan dipilih oleh pemilik UKM dalam mengembangkan usahanya. Bobot prioritas alternatif teknologi tiap sub kriteria dapat dihitung dengan melakukan perkalian antara bobot sub kriteria dengan bobot alternatif teknologi dengan sub kriteria. Selanjutnya pada tiap alternatif teknologi secara horizontal dijumlahkan. Untuk hasil perhitungan bobot prioritas alternatif terhadap sub kriteria keahlian operator dapat dilihat pada tabel 8 .

Tabel 8. Perhitungan bobot prioritas alternatif untuk sub kriteria keahlian operator

\begin{tabular}{|l|l|l|l|l|}
\hline \multirow{2}{*}{ KO } & \multicolumn{2}{|l|}{ Sub Kriteria } & $\begin{array}{l}\text { Bobot } \\
\text { sub } \\
\text { kriteria } \\
\text { no bobot } \\
\text { alternatif }\end{array}$ \\
\hline $\begin{array}{l}\text { Bobot } \\
\text { Alternatif }\end{array}$ & 0,601 & 0,170 & 0,229 & KO2 \\
\hline TAT & 0,643 & 0,602 & 0,548 & 0,615 \\
\hline TST & 0,283 & 0,315 & 0,211 & 0,272 \\
\hline TM & 0,074 & 0,082 & 0,241 & 0,114 \\
\hline
\end{tabular}

4.2.5 Penentuan prioritas alternatif teknologi yang terpilih

Penentuan prioritas alternatif teknologi akhir digunakan untuk menentukan peringkat alternatif teknologi dari nilai terbesar sampai nilai terkecil sehingga hasilnya dapat digunakan untuk melakukan analisis teknologi mana yang tepat bagi UKM Banyu Biru Craft yang nantinya akan disesuaikan dengan sistem kerja yang baru yang bisa meningkatkan produktivitas. Penentuan nilai prioritas alternatif teknologi akhir dengan mengalikan proporsi tiap kriteria, untuk hasil perhitungan penentuan kriteria bisa dilihat pada tabel 9 .

Tabel 9. Nilai prioritas alternatif teknologi akhir TAT, TST, dan TMT

\begin{tabular}{|c|c|c|c|c|c|c|c|}
\hline & \multicolumn{6}{|c|}{ Bobot Kriteria } & \multirow{4}{*}{$\begin{array}{l}\text { Bobot } \\
\text { Kriter } \\
\text { ia * } \\
\text { Bobot } \\
\text { Altern } \\
\text { atif }\end{array}$} \\
\hline & $\mathrm{KO}$ & UO & B & PF & MD & $\mathrm{KN}$ & \\
\hline \multirow{2}{*}{$\begin{array}{l}\text { Bobot } \\
\text { Alt }\end{array}$} & 0,0 & 0,3 & 0,1 & 0,2 & 0,0 & 0,1 & \\
\hline & 31 & 51 & 78 & 73 & 66 & 01 & \\
\hline \multirow[b]{2}{*}{ TAT } & 0,6 & 0,6 & 0,6 & 0,6 & 0,6 & 0,7 & \\
\hline & 15 & 51 & 40 & 50 & 76 & 37 & 0,658 \\
\hline \multirow[b]{2}{*}{ TSA } & 0,2 & 0,2 & 0,2 & 0,2 & 0,2 & 0,1 & \\
\hline & 72 & 69 & 83 & 77 & 43 & 69 & 0,262 \\
\hline \multirow[b]{2}{*}{ TM } & 0,1 & 0,0 & 0,0 & $\overline{0,0}$ & 0,0 & 0,0 & \\
\hline & 14 & 80 & 77 & 73 & 81 & 94 & 0,080 \\
\hline
\end{tabular}

Tabel 10. Ranking alternatif teknologi

\begin{tabular}{|l|l|l|}
\hline Alternatif Teknologi & Nilai Prioritas & Ranking \\
\hline Teknologi Otomatis & 0,658 & 1 \\
\hline Teknologi Semi-Otomatis & 0,262 & 2 \\
\hline Teknologi Manual & 0,080 & 3 \\
\hline
\end{tabular}

\subsubsection{Melakukan Focus Group Discussion (FGD)}

Setelah melakukan perhitungan Analytical Hierarchy Process (AHP) didapatkan suatu alterantif teknologi yang mempunyai prioritas tertinggi yaitu teknologi otomatis. Dengan terpilihnya alternatif teknologi otomatis, UKM membutuhkan perancangan sistem kerja yang baru untuk mentindaklanjuti alternatif teknologi tersebut. Perubahan untuk sistem kerja di UKM apabila teknologi otomatis tersebut diterapkan yaitu sebagai berikut.

1. Kebutuhan akan tenaga kerja.

Teknologi otomatis membutuhkan tenaga kerja yang memiliki tingkat pendidikan yang tinggi minimal Diploma. Dengan kebutuhan tenaga kerja yang spesifikasi memiliki keahlian tinggi, tentunya untuk upah 
akan semakin besar dengan menyesuaikan UMR di daerah tersebut.

2. Teknologi yang digunakan

Berdasarkan permintaan dari pemilik UKM Banyu Biru Craft, untuk teknologi yang digunakan yaitu mesin irat bambu. Mesin irat bambu yang diartikan disini sudah full otomatis jadi manusia hanya melakukan monitor saja. Namun pada saat ini untuk mesin irat bambu hanya ada yang semi-otomatis, manusia masih memiliki peran penting dalam pengoperasian mesin tersebut. Berikut gambar mesin irat bambu semi-otomatis yang sudah ada dipasaran.

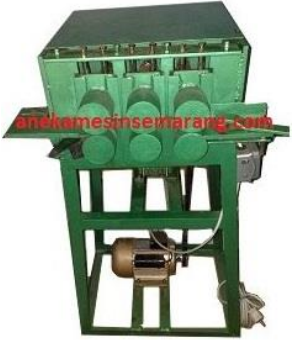

Gambar 3. Mesin irat bambu

(Sumber: anekamesinsemarang.com)

3. Lingkungan Eksternal

a. Sosio-ekonomi,

untuk

lingkungan sosio-ekonomi pada daerah Jipangan cukup baik. Perlu ditambahkan pekerja dibagian finishing supaya tingkat produksi kerangka kipas dan finishing seimbang.

b. Edukasi, tingkat pendidikan di daerah Jipangan perlu ditingkatkan dengan dilakukan pelatihan kerja dan manajemen produksi, serta perlu ditambahkan fasilitas penunjang produksi. Fasilitas tambahan untuk pemasaran yaitu pemasangan jaringan internet. Jaringan internet nantinya akan memudahkan pemilik UKM untuk melakukan pemasaran di dunia maya dan lebih mudah dalam melakukan komunikasi dengan calon konsumen.

Berdasarakan diskusi tentang sistem kerja yang baru untuk alternatif teknologi otomatis, dihasilkan bahwa untuk penerapan sistem kerja tersebut pada saat ini masih kurang tepat karena kondisi UKM masih dalam tahap berkembang. Keinginan dari pemilik UKM untuk memajukan produksinya masih belum bisa direalisasikan. Solusi yang bisa diterapkan dengan kondisi saat ini adalah memilih alternatif teknologi semiotomatis dengan sistem kerja yang tidak jauh berbeda dengan kondisi saat ini, hanya ada penggunaan mesin irat semi-otomatis utuk menggantikan pisau irat yang manual. Jadi untuk hasil dari focus group disscusion kali ini menghasilkan keputusan bahwa UKM tetap masih menggunakan sistem kerja yang lama untuk menjalankan produksinya karena untuk melakukan pengadaan mesin pemilik UKM belum bisa merealisasikan.

\subsection{Analisis Hasil}

\subsubsection{Analisis perhitungan AHP}

Pengolahan data dalam penelitian ini menggunakan metode AHP diperoleh bobot untuk masing-masing kriteria, sub kriteria, dan ranking alternatif akhir. Hasil perhitungan bobot dari masing-masing kriteria didapatkan urutan prioritas yaitu upah operator, peningkatan fungsi, biaya, kenyamanan, mudah digunakan, dan keahlian operator. Kemudian untuk hasil perhitungan bobot dari masing-masing sub kriteria pada kriteria yang ada dihasilkan prioritas paling tinggi yaitu upah rendah, lebih efisien, terjangkau, menyesuaikan bentuk tubuh, mempunyai buku panduan, dan keahlian tinggi. Sedangkan hasil ranking alternatif akhir didapatkan prioritas pertama yaitu teknologi otomatis dengan nilai prioritas sebesar 0,658.

\subsubsection{Analisis Sosioteknik}

Berdasarkan pemilihan alternatif teknologi dengan menggunakan metode AHP didapatkan prioritas tertinggi adalah 
teknologi otomatis. Dengan terpilihnya teknologi otomatis ini, maka diperlukan suatu sistem kerja yang baru. Sistem kerja yang baru ini dirancang berdasarkan sistem sosioteknik yang mempertimbangkan aspek personil atau tenaga kerja, aspek teknologi, dan aspek lingkungan. Sistem kerja yang baru adalah sebagai berikut.

1. Kebutuhan akan tenaga kerja.

Berbeda dengan kondisi tenaga kerja sekarang, dalam sistem kerja dengan teknologi otomatis membutuhkan tenaga kerja yang memiliki tingkat pendidikan yang tinggi minimal Diploma. Dengan kebutuhan tenaga kerja yang spesifikasi memiliki keahlian tinggi, tentunya untuk upah akan semakin besar dengan menyesuaikan Upah Minimum Kabupaten di daerah tersebut.

2. Teknologi yang digunakan

Berdasarkan permintaan dari pemilik UKM Banyu Biru Craft, untuk teknologi yang digunakan yaitu mesin irat bambu. Mesin irat bambu yang diartikan disini sudah full otomatis jadi manusia hanya melakukan monitor saja. Namun pada saat ini untuk mesin irat bambu hanya ada yang semi-otomatis, manusia masih memiliki peran penting dalam pengoperasian mesin tersebut.

3. Lingkungan Eksternal
a. Sosio-ekonomi,
untuk lingkungan sosio-ekonomi pada daerah Jipangan cukup baik, karena dekat dengan bahan baku, supplier, dan dekat dengan area pemasaran. Namun masih perlu ditambahkan pekerja dibagian finishing supaya tingkat produksi kerangka kipas dan finishing seimbang.
b. Edukasi, tingkat pendidikan di daerah Jipangan perlu ditingkatkan dengan dilakukan pelatihan kerja dan manajemen produksi, serta perlu ditambahkan fasilitas penunjang

produksi dan pemasangan jaringan internet.

Strategi yang lebih bisa diterapkan dalam kondisi UKM saat ini yaitu Alternatif Teknologi Semi-Otomatis. Dengan Teknologi Semi-Otomatis UKM hanya melakukan perubahan sedikit untuk sistem kerjanya. Hanya ada beberapa perubahan, seperti.

1. Kebutuhan Tenaga Kerja

Dalam alternatif teknologi semiotomatis untuk kebutuhan tenaga kerja membutuhkan tingkat pendidikan yang sedang yaitu SMP/SMA.

2. Teknologi yang digunakan

Terknologi yang digunakan yaitu mesin irat semi-otomatis, karena untuk mesin irat yang otomatis masih belum ada. Jadi untuk mesin yang bisa digunakan saat ini dan sudah ada dipasaran yaitu mesin irat semiotomatis.

3. Lingkungan Ekternal

Pada alternatif teknologi semiotomatis lingkungan eksternal yang dibutuhkan tidak jauh beda dengan kondisi saat ini. Penambahan lingkungan eksternal adalah pada penambahan jaringan internet, karena dengan adanya jaringan internet pemilik UKM bisa berkomunikasi secara langsung dengan calon konsumen.

\subsubsection{Analisis Produktivitas}

Dari hasil perhitungan kemampuan produksi dan produktivitas antara teknologi otomatis dengan kondisi sekarang ini hanya memiliki perbedaan pada tingkat produktivitas dan kemampuan produksi. Dilihat dari kemampuan produksi yang dihasilkan oleh teknologi otomatis memiliki kemampuan produksi yang besar yaitu 1920 bambu/bulan dibandingkan dengan kemampuan produksi sekarang ini sebanyak 192 bambu/bulan, namun untuk tingkat produktivitasnya masih rendah yaitu $0,019 \%$ dibandingkan dengan kondisi sekarang ini 
yang sebesar 0,026\%. Dalam hal ini UKM tidak mengalami peningkatan produktivitas yang signifikan, hanya mengalami peningkatan pada kuantitas saja. Selain hanya menambah kuantitas, UKM juga akan mengeluarkan biaya yang besar karena untuk membayar upah pekerja sebesar Rp. 1.163.800,- per bulan serta biaya pengadaan mesin sebesar Rp. 9.750.000,-. Sehingga untuk strategi penggunaan teknologi otomatis ini belum tepat diterapkan pada UKM Banyu Biru Craft karena kondisi UKM saat ini masih dalam tingkatan berkembang. Namun strategi ini bisa diterapkan saat UKM Banyu Biru Craft usahanya sudah maju. Sehingga untuk saat ini sistem kerja yang digunakan pada UKM Banyu Biru Craft masih menggunakan sistem kerja yang lama. Strategi yang baik digunakan pada UKM Banyu Biru Craft adalah alternatif teknologi semi-otomatis, dengan sistem kerja pada alternatif teknologi ini perubahan yang terjadi tidak terlalu signifikan hanya melakukan perbaikan pada teknologi yang digunakan yaitu dengan mesin irat semiotomatis.

\section{KESIMPULAN DAN SARAN}

\subsection{Kesimpulan}

Berdasarkan pengolahan data dan analisis data yang telah dilakukan didapatkan hasil dari pembobotan pada alternatif teknologi dengan menggunakan metode AHP yaitu teknologi otomatis yang memiliki bobot paling tinggi sebesar 0,658, perlu perancangan sistem kerja yang baru berdasarakan pendekatan sistem sosioteknik yaitu tenaga kerja yang digunakan memiliki tingkat keahlian tinggi dengan tingkat pendidikan minimal Diploma. Teknologi yang digunakan yaitu mesin irat, disesuaikan dengan kebutuhan proses produksi. Aspek lingkungan eksternal diperlukan lingkungan sosio-ekonomi yang dekat dengan bahan baku, supplier, area pemasaran, dan penambahan tenaga kerja bagian finishing. Lingkungan edukasi diperlukan penambahan jaringan internet dan pelatihan kerja dan manajemen produksi. Berdasarkan perhitungan tingkat produktivitas untuk teknologi otomatis yaitu sebesar 0,019\%. Hasil produktivitas teknologi otomatis tidak jauh berbeda dengan produktivitas kondisi sekarang ini yaitu sebesar $0,026 \%$. Teknologi otomatis dan sistem kerja yang baru belum bisa diterapkan pada UKM Banyu Biru Craft. Solusi untuk hal ini yaitu menjalankan strategi alternatif teknologi semi-otomatis yang dalam sistem kerjanya tidak mengalami perbedaan dengan sistem kerja yang diterapkan sekarang. Sehingga alternatif teknologi semi-otomatis bisa dijadikan pertimbangan untuk diterapkan pada UKM Banyu Biru Craft. Namun hasil dari focus group disscusion kali ini menghasilkan keputusan bahwa UKM Banyu Biru Craft tetap masih menggunakan sistem kerja yang lama untuk menjalankan produksinya.

\subsection{Saran}

Untuk perbaikan selanjutnya, ada beberapa saran yang dapat dijadikan pertimbangan bagi UKM dan penelitian selanjutnya. Saran-saran yang dapat diberikan penulis sebagai berikut:

1. Hasil penelitian ini diharapkan dapat digunakan UKM kerajinan kipas untuk memperoleh informasi dalam penentuan teknologi yang akan digunakan.

2. Saran bagi UKM adalah pengambil keputusan untuk penentuan teknologi harus lebih memperhatikan dan mempertimbangkan keahlian operator, upah operator, biaya, peningkatan fungsi, mudah digunakan, dan kenyamanan.

3. Untuk penelitian selanjutnya diharapkan untuk melakukan simulasi tentang produktivitas dari strategi yang telah dipilih.

\section{DAFTAR PUSTAKA}

Afiyanti, Y., 2008, Focus Group Discussion (Diskusi Kelompok Terfokus) sebagai Metode Pengumpulan Data Penelitian Kualitatif, Jurnal 
Keperawatan Indonesia, Vol. 12, No.

1, Hal 58-62, Universitas Indonesia, Depok.

Anggraini, I., 2010, Pemilihan Alternatif Sistem Manufaktur Industri Cor Logam Menggunakan Analytical Hierarchy Process (AHP), Skripsi, Universitas Pembangunan "Veteran" Yogyakarta, Yogyakarta.

Astuti, A.T., 2010, Intervensi Ergonomi Total Untuk Mengevaluasi Sistem Kerja pada Pengrajin Perak dengan Pendekatan Systemic, Holistic, Interdiciplinary, Participatorty (SHIP), Skripsi, Universitas Pembangunan "Veteran" Yogyakarta, Yogyakarta.

David, Fred R., 2002. Strategic Management. Person Education Asia Pte.Ltd, Edisi Bahasa Indonesia. Jakarta : PT.Prenhallindo.

Farabi, S.A., 2014, Analisis Perawatan Dengan Pendekatan Reliability Centered Maintenance (RCM) Dan Analytical Hierarchy Process (AHP) Pada Mesin Tenover Dan morticer, Skripsi, Universitas Pembangunan "Veteran" Yogyakarta, Yogyakarta.

Gitaya, V.H., 2014, Analisis Ergonomi Makro terhadap Tingkat Produktivitas Pekerja, Skripsi, Universitas Pembangunan "Veteran" Yogyakarta, Yogyakarta.

Hartanto, A., 2004, Strategi Clustering dalam Industrialisasi Indonesia, Andi. Yogyakarta.

Hendrick, H.W., 1987, Macro Ergonomics: A Concept Whose Time Has Come,

Human Factor Society Bulletin, Februari 1987.

Hendrick, H.W., dan Kleiner, B.M., 2001, Macroergonomics An Introduction To Work System Design, Human Factors and Ergonomics Society, Santa Monica, USA.

Iridiastadi, H., dan Yassierli, 2014, Ergonomi Suatu Pengantar, Cetakan Pertama, PT Remaja Rosdakarya, Bandung.

Ivancevich, J.M., Konopaske R., dan Matteson M.T., 2006, Organizational
Behavior And Management, Erlangga, Indonesia.

Jogiyanto, H.M., 2005, Sistem Teknologi Informasi

http://www.sarjanaku.com/2012/11/p engertian-sistem-menurut-paraahli.html, diakses pada 27 September 2015.

Manuaba, A., 2003, Penerapan Ergonomi Meningkatkan Produktivitas.

Makalah.

Denpasar : Bagian Ilmu Faal Fakultas Kedokteran Universitas Udayana.

Maringan, Y., 2015, Penentuan Prioritas Supplier dengan pendekatan Fuzzy AHP dan Fuzzy Topsis, Skripsi, Universitas Pembangunan "Veteran" Yogyakarta, Yogyakarta.

Marquez, C.A., 2007, The Maintenance Management Framework Models And Methods For Complex Systems Maintenance, Springer-Verlag, London.

Nurmianto, E., 2004, Ergonomi, Konsep Dasar dan Aplikasinya, Edisi Kedua, Prima Printing, Surabaya.

Nuryanto, A., Rahmawaty, P., Sutopo, dan Paryono, 2010, Peningkatan Produktivitas Kelompok Pengrajin Kipas di Jipangan Melalui Konsep Produksi Terpadu, Artikel, Universitas Negeri Yogyakarta, Yogyakarta.

Sinaga, J., 2009, Penerapan dan Pengertian Analytical Hierarchy Process (AHP), http://female.store.co.id/images/medi a/matematika\%20full\%20lagi.pdf, diakses pada 9 Agustus 2015.

Sutalaksana, I. Z., Anggawisastra, R., dan Tjakraatmadja, J. H., 1979, Teknik Tata Cara Kerja, Jurusan Teknik Industri, ITB, Bandung.

Untari, R., 2005, Pola Pertumbuhan Klaster Industri Kecil Indonesia, Disertasi Program Studi Teknik dan Manajemen Industri Institut Teknologi Bandung, Bandung.

Wardhana, R., 2013, Pengaruh Lingkungan Kerja Terhadap Produktifitas 
Pekerja (Studi Kasus: Industri

Kerajinan Gerabah Kasongan

Bantul), Skripsi, UGM, Yogyakarta.

Wignjosoebroto, S., 2000, Ergonomi Studi

Gerak dan Waktu, Guna Widya,

Jakarta. 